European Journal of Accounting, Auditing and Finance Research

Vol.8, No. 5, pp.16-32, May 2020

Published by ECRTD-UK

Print ISSN: 2053-4086(Print), Online ISSN: 2053-4094(Online)

\title{
EMPIRICAL INVESTIGATION OF CORPORATE TAX INCENTIVES IN NIGERIA: EVIDENCE FROM PANEL CAUSALITY TESTS
}

\author{
Dr. Sarakiri, James A. \\ Department of Banking and Finance, \\ Rivers State University \\ Nkpolu - Port Harcourt, Rivers State, Nigeria
}

\begin{abstract}
This study examines the effect of corporate tax on the market value of firms within the framework of the Modigliani and Miller modified work (1963). Using annual data from 1990 to 2016 of sixty (60) Nigerian quoted companies selected from different sectors of the country's economy, we adopted the panel data methodology to carry out an inferential statistical analysis with the aid of the Eviews package(version 9.5). Based on the adjusted $R$-squared, approximately sixty (60) percent of total variation in market value of firms is due to corporate tax. There is also evidence showing a highly significant linear relationship between corporate tax and market value of firms as well as a strong feedback influence running from market value of firms to corporate tax. These findings agree with the conclusion by Modigliani and Miller (1963) that the tax shields levered firms enjoy significantly enhance their market value. It is also an indication that the Nigerian government is subsiding cost of debt for the companies operating in the country's capital market.
\end{abstract}

KEYWORDS: Corporate tax incentives, market value of firm, panel data and causality tests.

\section{INTRODUCTION}

The seminal paper by Modigliani \& Miller (1958) provides a basis for any empirical investigation into issues relating to the relevancy or otherwise of capital structure decisions. Based on their findings, the firm operates within the purview of a perfect world where there are no transaction costs and corporate taxes. It could also be said that there are no asymmetric forces that can lead to information gaps between managers and investors. In such a world, the firm can finance its assets or new projects with any combination of debt and equity without any effect on its value. It therefore suggests that the firm's earnings power and business risk are the only determining factors for its market value.But Modigliani and Miller (1963) modified their earlier model by including corporate tax because interest paid on long-term debt is tax deductible and it provides incentives for the use of debt capital, and the more a firm uses debt, the more its profitability increases. So a levered firm tends to be more profitable than unlevered firm and this reflects on the value of the firm. Thus, firms that are levered have higher market value than firms that use only equity.

Based on this development and in response to the limitations of the irrelevance theory, several alternative theories explaining the relationship between capital structure and firm 
European Journal of Accounting, Auditing and Finance Research

Vol.8, No. 5, pp.16-32, May 2020

Published by ECRTD-UK

Print ISSN: 2053-4086(Print), Online ISSN: 2053-4094(Online)

value have emerged from the literature. Among the competing theories are the pecking order theory and the trade-off theory. The pecking order theory holds that managers rank their capital sources in order of preference, and prefer internal equity which is the cheapest finance source, over debt and new equity. They however prefer debt over equity when there is need for external financing. On the other hand, the trade-off theory holds that the value of a firm is maximized at the point of balance between the tax benefit of debt and the associated bankruptcy costs. Thus, both theories predict that there is a significant relationship between capital structure of a firm and its market value. However, while the pecking order theory predicts a negative relationship, the trade-off theory predicts a positive relationship (Myers and Majluf 1984, Campbell and Kelly 1994, Baker and Wurglar 2002 and Akeem 2014).

These theories and some recent other ones including the agency theory and the market timing hypothesis have been extensively tested empirically with a wide range of findings contributing to the literature on the effects of capital structure on market value of firms as well as related areas. For instance, Miller (1977) and Meyers (1984) maintain that the tax effect on firm value through debt financing is likely to be offset by other taxes such as personal income tax and dividends tax by shareholders. There are also other studies such as Bradley, Jarrel and Kim (1984), Baskin (1989), Barclay and Smith (1996), Chirinko and Singha (2000) and Pandey (2004) contributing to the debate on the direction of relationship between firm value and capital structure or debt financing. But the main issues of debate have not been resolved. So this study is designed to contribute to the empirical literature of corporate finance by identifying the tax incentives firms enjoy as a result of debt financing which ultimately would assist managers to build the correct mix of debt and equity in their capital structure.

The paper is arranged in five sections viz: following this introduction is literature review (section 2), while section 3 describes the sample and the techniques of data collection and analysis leaving section 4 for the empirical analysis as the last section (5) contains the discussion of the results and conclusion of the study.

\section{LITERATURE REVIEW}

Modigliani and Miller (1958) proposed the popular M and M theory which forms the basis of modern thinking in capital structure. The theory has two aspects cited as propositions 1 and II. The first proposition states that in a perfect market, the value of the firm is not affected by how that firm is financed. This means that firms are indifferent among all possible levels of capital structure. Proposition II deals with the overall weighted average cost of capital as a basis to determine the value of firm. The central point about this proposition is that an increase or decrease of a component of capital structure e.g. debt does not determine the overall weighted average cost of capital (WACC). This is so because such an increase or decrease is likely to be neutralized by an increase or decrease in the cost of another component such as equity thereby pushing overall weighted average cost of capital to a point of no effect. Therefore the weighted average cost of capital is likely to 
European Journal of Accounting, Auditing and Finance Research

Vol.8, No. 5, pp.16-32, May 2020

Published by ECRTD-UK

Print ISSN: 2053-4086(Print), Online ISSN: 2053-4094(Online)

be constant at all levels of capital structure and ultimately having no effect on firm value. This presupposes a linear relationship between cost of equity and debt-equity ratio.

However, a traditional view emerged which maintained that the firm can maximize its value through the judicious use of leverage which agrees with Modigliani and Miller (1963). This development is credited to the fact that the initial view of the two popular economists did not consider circumstances of the real world characterized by a number of factors among which are the following:

1. There are numerous cost elements associated with funding a business.

2. Shareholders or investors per se are bound to face some limitations in terms of access to material information due to asymmetric forces that exist in the world of business. 3. Businesses are also prone to various types of risk which are determined by among other things the different circumstances under which they operate.

4. Other than the physical costs noted above, economic transactions also have lemon costs that have the tendency to affect the value of firm.

5. Investors are highly rational and therefore cannot behave the same way under different business conditions.

In recognition of the above factors and the consistent intense argument on the irrelevancy of the $\mathrm{M}$ and $\mathrm{M}$ initial propositions, several alternative theories have emerged demonstrating in various ways how the relationship between capital structure and firm value exists. Prominent among them are the trade off theory, the pecking order theory, the agency theory and lately the market timing hypothesis all providing explanation for the relevancy of capital structure. According to Pandey (2005) the trade off theory provides the nexus which lies on the effect on profits emanating from corporate tax under debt financing suggesting that the incidence of tax is avoided because interest charges precede tax computations. Apparently, the cost of capital decreases as the proportion of debt increases which means managers would ordinarily prefer a no equity situation for the firm. But this is limited to the point where bankruptcy cost overides the benefits derived from the use of debt. So the preference for applying debt is seen from the tax benefit a company enjoys which becomes apparent as cost of capital decreases for an increased use of debt due to tax savings. Then this could continue until a point where bankruptcy cost would set in and the marginal benefit of further increases in debt declines with increases in debt as the marginal cost of bankruptcy increases. At this point, a trade off emerges which optimizes the overall value of the firm which becomes a suitable benchmark for choosing how much of debt and equity the company desires. We can also express the effect that the tax shields and bankruptcy cost could have on the value of a firm using leverage as follows: $\mathrm{VL}=\mathrm{D}+\mathrm{E}=\mathrm{VU}+\mathrm{PV}($ tax shields $)-\mathrm{PV}$ (bankruptcy cost)

where VL is market value of a levered firm, VU is the market value of the unlevered firm and the present values of tax shield and bankruptcy cost are denoted respectively as PV.

So within the context of the traditional approach to debt management, we have two advantages for the use of debt. First is the low cost of debt and secondly its flexibility which 
European Journal of Accounting, Auditing and Finance Research

Vol.8, No. 5, pp.16-32, May 2020

Published by ECRTD-UK

Print ISSN: 2053-4086(Print), Online ISSN: 2053-4094(Online)

are two important benefits a profitable company needing external finance to grow and develop could have. It is often a fairly low-cost source of finance. Interest on debt is an allowable charge for tax purposes and the cost of debt for a profitable company is therefore its after-tax cost derived as $\mathrm{Ta}=\mathrm{I}(1-\mathrm{T})$; where $\mathrm{Ta}$ is after tax cost of debt and I is interest on debt which is applied to the reciprocal of the tax rate. For example, if the tax rate on corporate profit is thirty percent (30\%), the effective after-tax cost of a debt with $20 \%$ interest is just $14 \%$ derived as follows:

$20 / 100$ applied to the reciprocal of the tax rate given as

$30 \%$ i.e. $20 / 100 \times 70 / 100=2 / 10 \times 7 / 10=14 \%$.

Devereux, Maffini and Xing (2018) found evidence of the effect of corporate tax on leverage showing statistically a positive relationship existing between capital structure and firm value which is traced to tax shield firms enjoy as a result of the use of debt. The findings from that study which utilized annual data from the United Kingdom provide good proof that leverage can respond positively to decreases in corporate tax in marginal terms particularly in the developed world. According to the authors, tax returns provide better explanatory power than data from the published statements of accounts suggesting that any research using data from the annual tax returns filed in by companies is likely to have superior results in the developed countries.

A cross sectional study by Antwi, Mills and Zhao (2012) also examined the impact of capital structure on firm value in Ghana. They made a regression analysis utilizing secondary data from all the thirty four companies listed on the Ghana Stock Exchange (GSE) for the year ended $31^{\text {st }}$ December 2010. Using the ordinary least square method of estimation, the study proved that equity capital has less effect than long term debt in the positive influence they both have on firm value. This result reveals that in an emerging economy like Ghana, equity capital as a component of capital structure is relevant to the value of a firm but Long-term-debt was found to be the major determinant of a firm's value which is also explained by the weight of tax and other non debt shields firms enjoy that promote the use of debt. To this end, corporate managers in Ghana are advised to employ more of long-term-debt than equity capital in financing their operations.

But the studies by Miller (1977) and Myers (1984) brought out some issues on the incidence of tax upon which Modigliani and Miller (1963) built their argument to support leverage as well as other empirical evidence in the corporate finance literature in the light of this argument. They suggest that the cost of corporate and personal taxes borne by shareholders are likely to offset the tax shields because both capital gains and dividends attract taxes from which the incidence avoided from company income tax would now be subjected to bear. This will undermine the advantages of debt financing because it is the tax relief that justifies the use of debt. Let us now illustrate this process beginning with the simple effect company income tax has on the value of a firm as follows:

Without tax, the value of firm is seen as

$\mathrm{V}_{\mathrm{L}}=\mathrm{V}_{\mathrm{U}}$ 
Where

$\mathrm{V}_{\mathrm{L}} \quad-\quad$ the levered firm value

$\mathrm{V}_{\mathrm{U}} \quad$ - the unlevered firm value

Introducing tax:

$\mathrm{V}_{\mathrm{L}} \quad=\quad \mathrm{V}_{\mathrm{U}}+\mathrm{tD}$

Where $\mathrm{V}_{\mathrm{L}}$ - levered firm value

$\mathrm{V}_{\mathrm{U}}$ - Unlevered firm value

tD - Marginal tax rate times D which denotes the amount of debt used by the firm.

Therefore the shield by tax or relief from tax provides the following effect:

(1) Lowers cost of debt

(2) Lowers the weighted average cost of capital (WACC) as more debt is used

(3) Increases the value of firm through the product of the tax rate and the volume of debt.

If we introduce these assumptions to our mathematical expression we would be able to derive a model as follows:

$W A C C(r)=\left[\frac{D}{V}(1-t)\right]+\left[\frac{E}{V} r e\right]$ and

$r e=r_{o}+\left(r_{o}+r_{d}\right)(1-t)\left(\frac{D}{E}\right)$

So as WACC reduces, there is the tendency for the value of the firm to move up in accordance with a proportionate amount of tax shield derived from the use of debt. However, the tax burden avoided under corporate income tax (CIT) is being transferred to bondholders who pay personal income tax and sometimes by owners who also pay tax on capital gains or dividends. This means the gains from leverage translate to losses incurred by bond and shareholders accordingly. The question is that is there any differential in times of value. The following expression provides a panacea to deal with such circumstances.

$G_{L}=\left[1-\frac{\left(1-\tau_{c}\right)\left(1-\tau_{P S}\right)}{1-\tau_{P B}}\right] B_{L}$

Where rc is the corporate tax rate, rPS is the personal income tax applicable to income from common stock, rPB is the personal income tax derived from bonds, while BL is the market value of the firm's debt.

The illustration shows that the advantage of tax deduction merely offsets the disadvantage of being included in the personal income tax of investors. Given their behavioural patterns, unless managers pay higher interest they would ordinarily like to look for alternatives and no matter how much they increase the volume it would be indifferent because personal income tax is progressive. The two explanatory variables are expressed at the right side of the model above. The numerator is the adjusted tax shield gained from leverage which depends further on the amount of tax paid on income from bonds expressed as a denominator which ordinarily would limit the power of the numerator.

However we can determine interest rates for debt instruments that would be beneficial to 
European Journal of Accounting, Auditing and Finance Research

Vol.8, No. 5, pp.16-32, May 2020

Published by ECRTD-UK

Print ISSN: 2053-4086(Print), Online ISSN: 2053-4094(Online)

both parties with a graphical illustration showing an equilibrium which would signify the optimum point at which both buyers and sellers are willing to strike a deal.

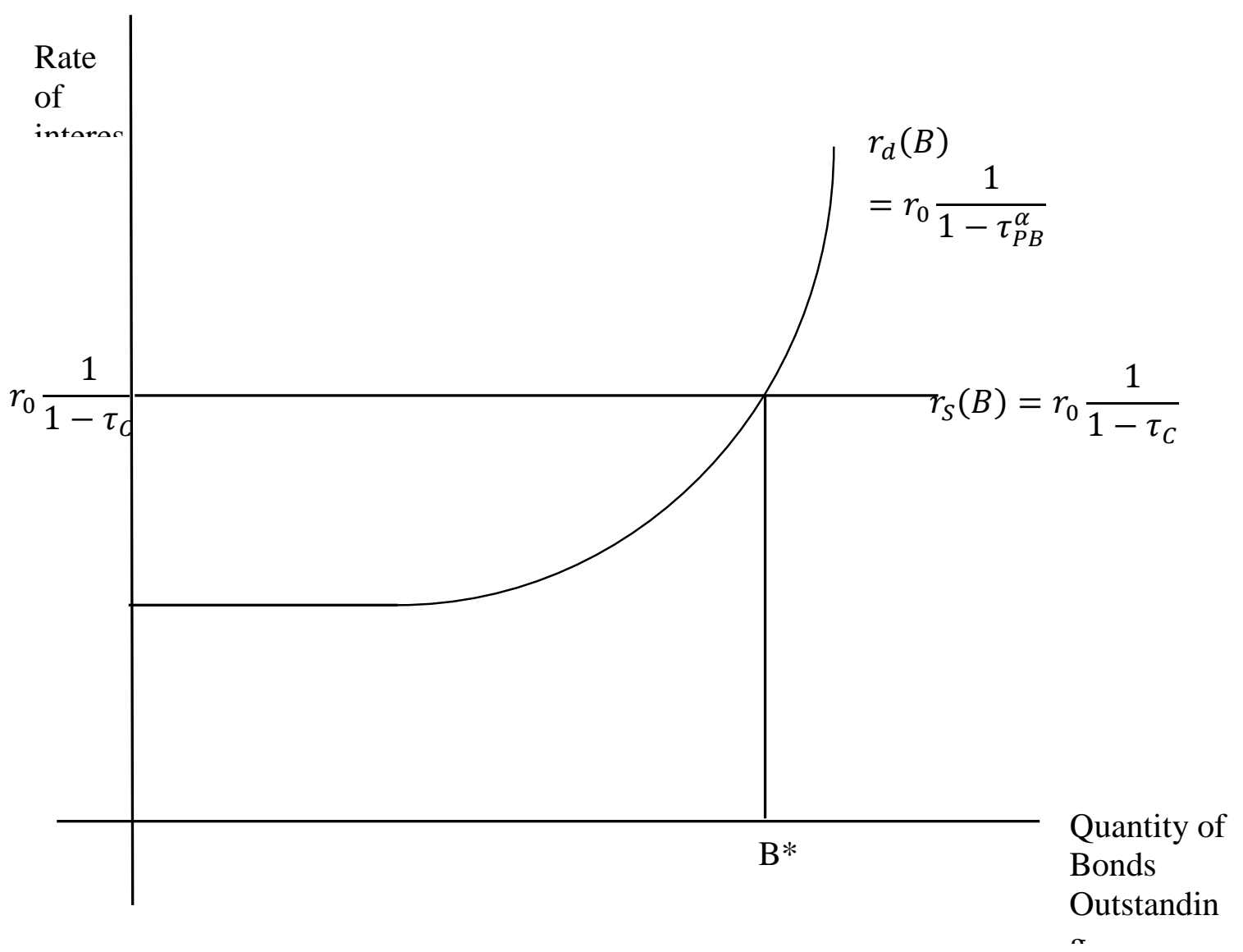

Figure 1. Equilibrium Analysis for bond trading

Source: Miller (1977). Debt and Taxes, Journal of Finance, 32(2), p269.

From figure 1 above, the demand and supply of debt instruments represented by corporate bond shows the effect of personal income tax on debt through the incidence of tax savings from the use of debt. An investor in debt instrument with a given personal income tax is likely to lose his marginal earnings from tax savings gained by the company he invested. However the model is based on aggregates and it may not truly show accurate effects on the burden an investor may bear. But it can serve as a panacea for firms to articulate debt policy that would reflect targets as means of measuring dispersion. The diagram shows clearly that any point above the equilibrium attracts higher interest.

Myers (1984) provides a basis to argue that the static assumption of the tradeoff theory affects financing behaviour through targets that tend to determine cross sectional dispersion of actual debt ratios. Then we have factors such as business risk, firm characteristics, non debt shields which arise from investment credits and the payout policy that limit the margin 
European Journal of Accounting, Auditing and Finance Research

Vol.8, No. 5, pp.16-32, May 2020

Published by ECRTD-UK

Print ISSN: 2053-4086(Print), Online ISSN: 2053-4094(Online)

of tax shields firms enjoy and they can add to establish a compromise region demonstrated below.

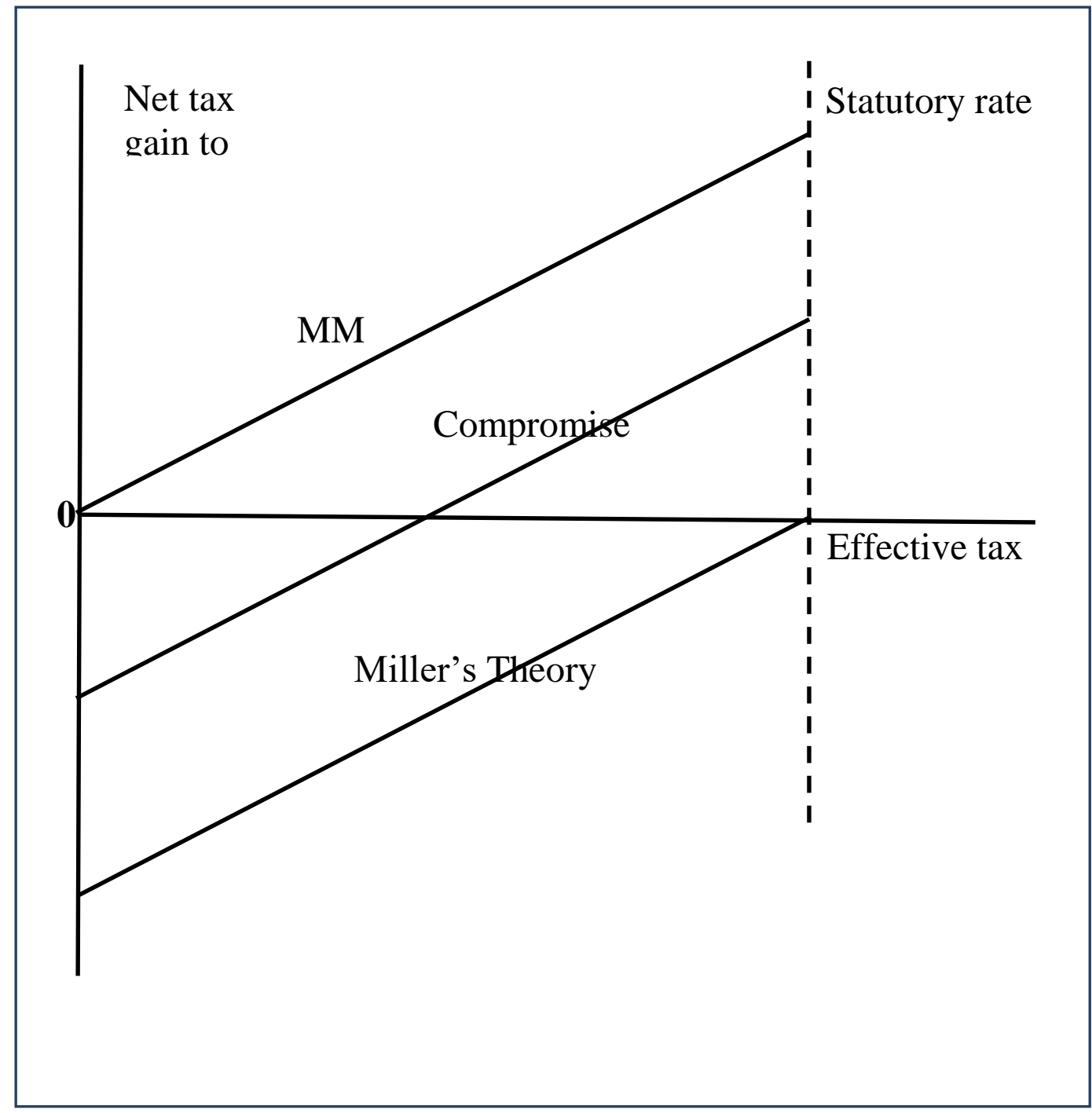

Figure 2. Effective Tax

Source: Myers(1984). The capital structure puzzle, Journal of Finance, 39(3). p 581

In Andras, Rettl and Whited (2014), the idea that leverage is negatively correlated with measures of profitability is disputed. In contrast, at times when firms are close to their optimal level of leverage, the cross-sectional correlation between profitability and leverage is positive. At other times, it is negative. These results are consistent with dynamic trade off models by Miller (1977) suggesting that they are not driven by factors such as investment opportunities, market timing strategies, payout or reversion of leverage policies. Instead they are influenced by the tax and other non-debt shields firms' enjoy.Tetman and Wessels (1988) viewed Scott's model on capital structure and observed 
European Journal of Accounting, Auditing and Finance Research

Vol.8, No. 5, pp.16-32, May 2020

Published by ECRTD-UK

Print ISSN: 2053-4086(Print), Online ISSN: 2053-4094(Online)

that firms with sufficient assets to secure debts are likely to have more debt in their capital structure. But then debt increases have the tendency to cause increases in the value of equity subject to better corporate governance and management proficiency in the effective utilization of such debts. In their findings, firms with low debt ratios are not likely to have high distress costs and they maintained that under the tax shield, government is subsiding the cost of debt.

To Yu-Shu and Chu-Yang (2010), a triple-threshold effect exists between leverage and firm value signifying a correlation but identified a definite level beyond which a further increase in debt financing does not improve proportional firm value. This gives empirical support to the tradeoff theory providing a basis for tax shields to continuously knock off debt financing costs until a point where increasing agency costs and distress/bankruptcy costs begin to emerge and grow to cover the shields. So in their view both the trade off and agency theories pose limitations to the application of tax and other non-debt shields.

In Nigeria, Toby (2010) used Earnings Per Share (EPS), Dividends Per Share (DPS), Asset growth, turnover, net profit and shareholders fund as proxies for Corporate Performance to study the effect financial, operating and even combined leverage could have on them. But the results show that only turnover and profitability have statistically significant inverse correlation with leverage.

Lawal (2014) examines the effects of both equity and debt on the market value of Nigerian banks using ordinary least squares (OLS) method of data analysis. The study is based on panel data consisting of 15 cross sectional units (quoted commercial banks) covering the period 2007 to 2012. The results provide evidence that firm value is significantly related to both equity and debt in a linear fashion. This indicates that Nigerian banks can effectively utilize debt. These studies bring out the reality of the imperfections inherent in the real world which are information asymmetries, bankruptcy cost, agency cost and the gains derivable from leverage induced by tax reliefs.

\section{METHODOLOGY}

The choice of panel data methodology is based on the suitability it provides for a study of this nature. According to Brooks (2008), a data set is panel if it consists of both time series and cross-sectional elements. So it is a kind of longitudinal data consisting of repeated observations on variables for large numbers with cross-sections in stacked form like individuals, organizations, industries or countries while the time series observations can be hourly, daily, weekly, monthly, quarterly and yearly. If $N$ represents the cross-sectional units and $T$ represents the time series observations, then, there are a total of $N \times T$ observations for the panel data. With the combination of both time series and crosssectional dimensions, it provides a rich dataset sufficient for asymptotic benefits as well as

a better framework for modeling cross-sectional heterogeneity than the cross-sectional data type. 
European Journal of Accounting, Auditing and Finance Research

Vol.8, No. 5, pp.16-32, May 2020

Published by ECRTD-UK

Print ISSN: 2053-4086(Print), Online ISSN: 2053-4094(Online)

A panel data is balanced if all the cross-sectional units have equal date observations. There is no missing date observation for a balanced panel data. On the contrary, an unbalanced panel dataset contains some missing date observations. In other words, an unbalanced panel data contains unequal date observations for the cross-sectional units.

A panel dataset is short if it consists of few date observations and large cross-sectional units. Thus, for a short panel data, the cross-sectional dimension $N$, is relatively large while the time series dimensionT, is relatively small (i.e. $N>T$ ). On the contrary, when small cross-sectional units $N$, are observed over a long time $T$, we say that the panel data is long (i. e. $N<T$ ). The choice between long and short panel data depends on (1) data availability and (2) the assumption made on cross-sectional heterogeneity. If the date observations on each cross-sectional unit are richly available and the cross-sectional heterogeneity or individual-specific effects vary with time, then a long panel data is appropriate. On the other hand, a short panel data may be used if date observations are in limited supply and the individual effects are time invariant.

All the companies listed in the Nigerian stock exchange form the population of this study. As at 2016 financial year, there are a total of 170 companies or securities (NSE, 2016) which are categorized into 12 industries or sectors, namely: Agriculture, Construction/Real Estate, Consumer Goods, Financial Services, Health Care, Industrial Goods, Information and Communication Technology (ICT), Natural Resources, Oil and Gas, Services, Utilities and Conglomerates.

A total of 60 companies are used in this study which represents about $36 \%$ of the population. Non-probability sampling technique is used to select the sample. Specifically, the 60 companies are purposively selected from the 12 industries or sectors (at least 5 in each industry) that constitute the study population. The period covered is twenty seven years from 1990 to 2016. Thus, the sample consists of $1,620(N \times T)$ panel data observations. Other criteria used for selecting the companies are:

1. The companies must have been listed in the Nigerian stock exchange for the years within this period.

2. The companies must have consistently published their reports and accounts for twenty seven years covering the entire period(1990 to 2016).

3. The companies were not acquired in any form within this defined study period.

4. The companies (especially banks) have no issues of bad debt or non-performing loans.

It is our view that observations on 60 companies for twenty seven years period fit the definition of panel data as emphasized previously. It is also our view that a sample size of 1,620 data points is sufficient to obtain consistent, unbiased and reliable results that will truly represent the population. 
European Journal of Accounting, Auditing and Finance Research

Vol.8, No. 5, pp.16-32, May 2020

Published by ECRTD-UK

Print ISSN: 2053-4086(Print), Online ISSN: 2053-4094(Online)

Yearly time series observations for the 60 selected companies are used. The variables are market value per share and corporate tax. The data on the study variables are obtained through secondary sources. Specifically, the data are collected and computed from annual reports and accounts of the selected companies for different years submitted at the Nigerian Stock Exchange obtained at the Port Harcourt branch.

\section{Methods of Data Analysis}

Basically, there are three different models and/or methods of data analysis within the panel data framework, namely; pooled regression, fixed effects and random effects models.

The first stage in data analysis in the panel data framework is to run a pooled least square regression, which involves pooling all the data together regardless of the heterogeneity in them or cross-sectional differences (Brooks, 2008). One alternative to the pooled least square approach that accommodates the heterogeneity in the panel data is the fixed effects approach. The fixed effects model can be specified as follows:

$Y_{i t}=\left(\alpha+\gamma_{i}\right)+X_{i t} \beta+\epsilon_{i t}$

In comparing the fixed effects model with the pooled model, the latent parameter $\gamma_{i}$ accounts for the cross-sectional heterogeneity that affects $Y_{i t}$ but does not vary with time. The cross-sectional heterogeneity may be in the form of differences in managerial styles and culture of different companies or industries where firms operate and compete etc. (Brooks, 2008). Thus, the fixed effects approach accommodates the cross-sectional heterogeneity or differences which are not directly observable by including the latent parameter $\gamma_{i}$ in the model.

The second alternative to the pooled regression model, which also accommodates the crosssectional heterogeneity in panel data, is the random effects model.

Model Specificaion

The functional specification of the relationship between corporate tax and the market value of firms is expressed in a model as follows:

$M V S=f(T A X, T A N G)$

where;

$M V S=$ Firm market value per share or share price

$T A X=$ Corporate tax

The econometric parameterization of the above model is given below:

$M V S_{i t}=\gamma_{0}+\gamma_{1} T A X_{i t}+\gamma_{2} T A N G_{i t}+v_{i}+\mu_{i t}$

where, $\gamma_{0}$ is the regression constant, $v_{i}$ represents the unobserved firm-specific factors and $\mu_{i t}$ the disturbance terms while the parameter $\gamma_{1}$ is the regression slope which is also constant cross-sectionally. If the latent variables are found to be not significant, then the model is a pooled regression specification. On the other hand, if these latent factors are significant and correlate with the independent variables, then our model is a fixed effect 
European Journal of Accounting, Auditing and Finance Research

Vol.8, No. 5, pp.16-32, May 2020

Published by ECRTD-UK

Print ISSN: 2053-4086(Print), Online ISSN: 2053-4094(Online)

specification. If there is no such correlation, then our model is a random effect specification and can be estimated using the GLS technique. There is therefore, good reason to consider the two hypotheses associated with the conventional panel data methodology; (1) the unobserved firm-specific variables are jointly not different from zero and (2) the unobserved firm-specific factors are uncorrelated with the observed variables. A rejection of the first hypothesis would imply that the unobserved firm-specific effects are important determinants of the market value of firms listed in the Nigerian stock exchange and ignoring these important variables would lead to heterogeneity bias. Thus, the pooled least square model is not the plausible description of our panel data.

Furthermore, we also have panel causality tests which are tests of restrictions on the lag coefficients of an endogenous variable in an autoregressive model or VAR models and are usually implemented within the F-test framework (Brooks, 2008). To determine whether there is a causal relationship between corporate tax and firm value, we consider the following general linear bivariate model in the context of panel data:

$M V S_{i t}=\alpha+\sum_{k=1}^{K} \beta_{k} M V S_{i t-k}+\sum_{k=1}^{K} \delta_{k} T_{i t-k}+\gamma_{i}+\varepsilon_{i t}$

$T_{i t}=\alpha+\sum_{k=1}^{K} \theta_{k} T_{i t-k}+\sum_{k=1}^{K} \phi_{k} M V S_{i t-k}+\gamma_{i}+\varepsilon_{i t}$

Where $T$ is the corporate tax,$k$ is the highest number of lags while other parameters are as defined previously. If the lag coefficients on $T \delta_{k}$, are jointly significant, other things being equal, then we can reject the null hypothesis that $T$ does not Granger cause $M V S$ and conclude that there is unidirectional causality running from corporate tax to firm market value. On the other hand, if the lags of the lag coefficients on $M V S \phi_{k}$, are jointly significant, other things being equal, then we can reject the null hypothesis that $M V S$ does not Granger cause $T$ and conclude there is unidirectional causality running from firm market value to capital structure. Further, if both $\delta_{k}$ and $\phi_{k}$ are significant, then we conclude that there is feedback or bidirectional causal relationship between corporate tax and firm value. However, if $\delta_{k}$ and $\phi_{k}$ are not significant, we can say that both corporate tax and firm market value are independently related.

Apart from the usual t-test and F-test which are intended to be used to test the significance of the individual betas and the feedback causality between the firms' market value and corporate tax, we adopt other hypothesis testing methods under the panel data framework such as the Likelihood ratio (LR) test and the Hausman Specification test. These tests are also used to choose the best panel data model for our sample and data.

\section{Emperical Results}

Table 1 shows the estimation results and goodness of fit statistics based on the three panel data models; pooled regression, fixed effects and random effects, as specified in section 3 . The model expresses market value of firm (MVS) as a function of corporate tax (TAX). 
European Journal of Accounting, Auditing and Finance Research

Vol.8, No. 5, pp.16-32, May 2020

Published by ECRTD-UK

Print ISSN: 2053-4086(Print), Online ISSN: 2053-4094(Online)

Table 1: Panel estimation results

\begin{tabular}{cllllll}
\hline Variable & Pooled Estimate & $\begin{array}{l}\text { Fixed } \\
\text { Estimate }\end{array}$ & Effects & $\begin{array}{l}\text { Random } \\
\text { Estimate }\end{array}$ \\
\hline Constant & $0.5648(0.0000)$ & 0.9582 & $(0.0000)$ & 0.9056 & $(0.0000)$ \\
LTAX & $0.3027(0.0000)$ & 0.1965 & $(0.0000)$ & 0.2054 & $(0.0000)$ \\
LT ANG & -0.0384 & $(0.0560)$ & -0.0312 & $(0.0647)$ & -0.0308 & $(0.0663)$ \\
R-squared & 0.2098 & 0.6219 & & 0.0979 & \\
Adj. R-squared & 0.2087 & 0.6050 & & 0.0966 & \\
F-statistic & $185.2407(0.0000)$ & 36.6632 & $(0.0000)$ & $75.7492(0.0000)$ \\
Durbin-Watson & 0.3410 & 0.6524 & \multicolumn{2}{l}{0.6263} & \\
\hline
\end{tabular}

Source: E-Views output; Bracket ( ) contains $p$-values

From the table, we can see the estimates of the three models are broadly similar, with the coefficient on LTAX (beta $>0$, p-value $=0.0000$ ) consistently having a positive sign and a very low probability. Thus, firm market value is a positive and highly significant function of corporate tax.

For all methods, The F-statistic is quite high with zero probability ( $\mathrm{p}$-value $=0.0000$ ), suggesting that the joint effect of tax and tangibility on firm market value is highly significant. However, the fixed effects model $(=0.6050)$ has a much higher Adjusted Rsquared than both the random effects $(=0.0966)$ and pooled regression $(=0.2087)$ models, suggesting that the fixed effects method fits our panel data much better than its rivals. Thus, the proportion of the total variation in firm market value that is due to corporate tax is approximately $60 \%$ for fixed effects model and $9 \%$ for random effects model and $20 \%$ for pooled regression model. Similarly, the fixed effects model has the highest Durbin-Watson value $(\mathrm{DW}=0.6524)$ compared to both random effects model $(\mathrm{DW}=0.6263)$ and pooled regression method $(\mathrm{DW}=0.3410)$. Therefore, the fixed effects approach seems to be the best fitting model for the relationship.

From the table, the p-value corresponding to LTAX (log of corporate tax) for random effects model is 0.0000 which is substantially lower than 0.05 . We therefore, strongly reject the null hypothesis and conclude that there is a highly significant relationship between corporate tax and market value of quoted firms in Nigeria.

Table 2 shows the formal specification test results for the relationship. Both Likelihood ratio and Hausman tests are also shown. For Likelihood ratio test, which formally compares the pooled regression model with the fixed effects model, the null hypothesis is that the firm-specific factors are not significant explanatory variables in the model. A rejection of this test assumption would imply that the fixed effects estimates are more reliable than those of the pooled regression model. For Hausman specification test, the comparison is between the fixed effects model and random effects model under the null hypothesis that firm-specific factors are uncorrelated with corporate tax. 
European Journal of Accounting, Auditing and Finance Research

Vol.8, No. 5, pp.16-32, May 2020

Published by ECRTD-UK

Print ISSN: 2053-4086(Print), Online ISSN: 2053-4094(Online)

Table 2: Model selection tests

\begin{tabular}{lll}
\hline Test & Chi-square statistic & $p$-value \\
\hline Likelihood Ratio test & 1030.694 & 0.0000 \\
Hausman Test & 4.4058 & 0.1105 \\
\hline
\end{tabular}

Source: E-Views output

From the table, we can see that while Likelihood ratio test is highly significant ( $\mathrm{p}$-value = 00000), the Hausman specification test is not significant even at $10 \%$ level ( $\mathrm{p}$-value $=$ 0.1105). Thus, we strongly reject the pooled regression estimates in favour of those of fixed and random effects and conclude that the unobserved firm-specific variables are significant variables in our empirical model. Further, we do not reject the null hypothesis of random effects model and so the firm-specific effects are uncorrelated with corporate tax.

Table 3 shows the pairwise Granger causality test results for corporate tax and firm market value. The causality from corporate tax to firm market value is tested under the null hypothesis that LTAX does not Granger Cause LMVS. A rejection of this null hypothesis would imply evidence of a unidirectional causality from corporate tax to firm market value. On the other hand, the reverse causality is tested under the null that LMVS does not Granger cause LTAX. A rejection of this null would imply evidence of a unidirectional causality from firm market value to corporate tax. However, if both null hypotheses are rejected, then there is evidence of feedback causality between firm market value and corporate tax. On the contrary, if both hypotheses are not rejected, then there is no causality between the two variables. Again, we include only one lag of each variable in each test equation.

Table 3. Causality test between firm market value and corporate tax

\begin{tabular}{lcl}
\hline Null Hypothesis & F-statistic & Probability \\
\hline LTAX does not Granger Cause LMVS & 20.7901 & 6. E-06 \\
LMVS does not Granger Cause LTAX & 16.4048 & 5.E-05 \\
\hline
\end{tabular}

Source: E-Views output

From table 3, we can see that the associated probability of the F-statistic (p-value $<0.05$ ) is very low in both cases, suggesting that the test is highly significant. Therefore, both null hypotheses are strongly rejected. Thus, there is a bidirectional or feedback causal link between corporate tax and market value of shares quoted in the Nigeria Stock Exchange.

\section{DISCUSSION OF FINDINGS}

Our study agrees with the work of Devereux, Maffini and Xing (2018) which came out with findings explaining the behavour of firms in the developed world with the impact leverage creates on their value as a result of tax shields. This also confirms the revised work of Modigliani and Miller (1963) and the fact that leverage is enhanced by the amount of corporate tax through the shields provided from the deductions the firms are expected to make in their income statements. Our results now confirm these findings. 
European Journal of Accounting, Auditing and Finance Research

Vol.8, No. 5, pp.16-32, May 2020

Published by ECRTD-UK

Print ISSN: 2053-4086(Print), Online ISSN: 2053-4094(Online)

Also, De Jong (2002) established a bidirectional relationship between leverage and firm value with evidence that long term debt significantly affects firm value which in turn influences leverage through corporate tax. From his study, conclusions emerge that there is a reverse effect on leverage from market value of firms and the latter is enhanced by increased tax shields arising from leverage. These findings are also supported by the results of our pairwise panel causality test shown in section four.

It is pertinent to mention that the value of a firm is expressed in terms of both the value of levered firm and unlevered firm with the former defined as the sum of total debt and equity at any given time. However, in estimating the value of a levered firm it would be appropriate to derive an econometric expression that captures a relationship with an unlevered firm which is added to a value derived from the present value of the amount of corporate tax deducted by the present value of any associated cost from possible bankruptcy the firm may likely experience. Therefore we must define clearly the concept of tax shield which is the factor bringing about the advantage in the use of leverage as established in the revised work of Modigliani and Miller (1963).

A tax shield can be expressed in terms of the interest on debt and a prevailing tax code in an economy as well as the proceeds likely to be generated from the use of the funds borrowed. Then the amount of shield a company can enjoy is obtained from the product of interest and the tax rate denominated by the amount of proceeds expected from the use of the borrowed funds.

From Miller (1977) and Myers (1984), there are limitations about corporate tax as a variable to determine firm value owing to the existence of personal income tax, capital gains tax and other forms of shield such as depreciation and investment credits from financial leases which would reduce the taxable profit. However, they advocate the use of earnings before interest, depreciation and taxes (EBIDT) as a proxy to be able to establish the actual effect corporate tax could have on firm value. This explanation does not limit the findings on the effect of corporate tax on the value of the quoted firms and vice versa. However, the other forms of shield that reduce taxable profits and by extension enhance distributable profit or increase the value of firms are not alternatives. Secondly all the factors that contribute to tax shield are independently determined by the prevailing tax rate on one hand and the volume of each item on the other hand. For instance, a tax rate of 40 percent would provide different amount of shield from loans, investment credits and depreciation all according to the volume of each. In our view, rather than seeing them as competing factors, they are various ways of providing shields to enhance the value of firms. Titman and Wessels (1988) found empirical evidence that these non debt tax shields have substantial effect on the value of firms. The question then is what are the indicators of the non debt tax shields and how do they enhance the value of firms to be able to relate their effect to the findings of this study. Then we can also relate this to the findings of Miller (1977) and Myers (1984) to be able to confirm an effective tax amount that attracts the shield firms actually enjoy. 
European Journal of Accounting, Auditing and Finance Research

Vol.8, No. 5, pp.16-32, May 2020

Published by ECRTD-UK

Print ISSN: 2053-4086(Print), Online ISSN: 2053-4094(Online)

Again, the ratio of investment tax credits to total assets explains clearly the extent to which provisions for exemptions in tax are made from the amount of investments a company makes in assets whether by internal or external funds. A higher ratio signifies a higher non debt shield providing explanation that much of increase in firm value is traced to investments in assets that are derived through leases and other related means of financing corporate growth.

Another factor that indicates non debt shield is operating income which is derived from gross profit before deducting depreciation, interest charges and tax. Its main determinants are operating cost and gross profit further determined by the extent to which managers are able to cut down costs of raw materials. The tendency is that operating income moves in the same direction with market value of shares of the company.

Interest payments take the form of investment credits and are both allowances that reduce the taxable income and in effect the amount of tax a firm is required to post. Judging from theoretical knowledge, the more allowances created by these credits the less the amount of tax payable thereby establishing an inverse relationship between all forms of investment credits including interest payments and corporate income tax.

Furthermore, both long term debt and leases can provide double effects on taxable income through the shields if the borrowed funds are used to acquire fixed assets. This is so due to the fact that the interest payments are exempted from tax and the assets also provide depreciation allowances both bringing about shields in different ways.

Most profoundly, this study proves that corporate tax has a strong explanatory power on the market value of shares quoted in the Nigeria Stock Exchange with a feedback response justifying a bidirectional relationship between the two variables.

The foregoing proves clearly that our findings show some level of consistency with previous works within the subject matter and in some cases expanded the findings of earlier works thereby becoming more robust. This is made possible by the considerably wider scope and the fact that the study took account of all stages about the Nigerian economy with its very strategic emerging market posture. For instance, just like the study of Pandey (2001) which covered the periods of downturn and upturn in the Malaysian economy, ours took its scope from 1990 when the Nigerian Capital Market was at its infant age and extended up till 2017 with a tendency to among others capture very recent developments.

\section{CONCLUSION}

The study conclude that the relationship between corporate tax and market value of quoted firms in Nigeria is found to be significant and also bidirectional. Based on the empirical analysis, corporate income tax has a linear relationship with the value of firm and at the same time there is a feedback effect running from the value of a firm to capital structure through corporate tax. So any change in the amount of corporate income tax a firm records, 
European Journal of Accounting, Auditing and Finance Research

Vol.8, No. 5, pp.16-32, May 2020

Published by ECRTD-UK

Print ISSN: 2053-4086(Print), Online ISSN: 2053-4094(Online)

there is the tendency that it would cause changes of about twenty one percent $(21 \%)$ in the market value of shares of these companies as explained by the coefficient of determination. Invariably, changes in the market value of shares would cause reverse effect in the amount of corporate tax the companies are required to post to their profit and loss statements explained by an F statistics of 16.4048. These findings are robust with few empirical works supporting various aspects.

Corporate tax is proved to be a key determinant of decision making in the use of debt by the companies studied. This is evident in view of the bidirectional relationship established between tax and the value of the firms which is highly significant at both levels. It is therefore a basis to extend the key principle entrenched in the modified work by Modigliani and Miller (1963) beyond the trade-off theory as articulated by Pandey (2005). However, the tax data obtained from the annual reports pose a threat to the reliability of this result because Devereux, Maffini and Jing(2018) also found evidence that tax figures from published financial statements in the United Kingdom provide a weaker explanatory power.

\section{Recommendation}

The study therefore recommends among others that the Nigerian government needs subsidize cost of debt-financing for the companies operating in the country's capital market.

\section{References}

Akeem, L. B. (2014). Effect of capital structure on firm performance, Journal of finance and Investment, 3(4), 39-57.

Andras, D., Rettl, D. A. and Whited, T.M. (2014).Refinancing, Profitability, and Capital Structure, Journal of Financial Economics, 1(3), 1-20.

Antwi, S., Mills, E. F. E. A., \& Zhao, X. (2012). Capital Structure and Firm value: Empirical evidence from Ghana. International Journal of Business and Social Science, 3(22), 103-110.

Baker, M. \& Wurglar, J. (2002). Market timing and capital structure, The Journal of Finance, 57(1), 2-31.

Barclay, M.J. \& Smith, C.W. (1996). On financial architecture: Leverage, maturity and priority, Journal of applied Corporate Finance, 12(1), 8-20.

Baskin, J. (1989). An empirical investigation of the pecking order hypothesis, Journal of Financial Management, 1(1), 26-35.

Bradley, M., Jarrel, G.A. \& Kim, E.H.(1984). On the existence of optimal capital structure: Theory and evidence, Journal of Finance, 39(7), 857-878.

Brooks, C. (2008). Basic Econometrics for finance. Cambridge University Press, New York.

Campbell, D.E. \& Kelly, J.S.(1994). Applications of the trade off theory, American Economic Review, 84(2), 422-426.

De Jong A. (2002).The disciplining role of leverage in Dutch Firms, European Finance Review, 6(1), 31-62. 
European Journal of Accounting, Auditing and Finance Research

Vol.8, No. 5, pp.16-32, May 2020

Published by ECRTD-UK

Print ISSN: 2053-4086(Print), Online ISSN: 2053-4094(Online)

Devereux, M. Maffini, G. and Xing (2018). Corporate tax incentives: New evidence from U.K, Journal of Banking and Finance, 88(3), 250-266.

Faccio, M. \& Jin, X. (2015). Taxes and capital structure, Journal of Financial and Quantitative Analysis, 50(3), 277-300.

Green, W. H. (2002). Econometrics analysis. New Jersy, Prentice Hall.

Green, W. H. (2003). Econometrics Analysis. New Jersey, Prentice Hall

Hausman, J. A. (1978). Specification tests in econometrics. Econometrica. 46, 1251-1272.

IHS. (2015). E Views: E Views 9 User's Guide II. Irvine: HIS Global Inc.

Lawal, A . 1. (2014). Capital structure and the value of the firm: Evidence from the Nigerian banking industry, Journal of Accounting and Management, 4, (1), 31 41.

Lonca, T. R. and Caldeira, J. F. (2013). Capital structure, cash holdings and firm value: A study of Brazilian listed firms. Review of Financial Studies, 20(5), 1429-1420.

Miller, M.H. (1977). Debt and taxes, Journal of Finance, 32 (2), 1-9.

Modigliani, F., \& Miller, M. H. (1958). The cost of capital, corporation finance and the theory of investment. The American Economic Review, 48(3), 261-297.

Modigliani, F.\& Miller, M. H. (1963). Corporate income taxes and cost of capital: A correction. The American Economic Review, 53 (3), 433-443.

Myers, S.C.(1984) The Capital Structure Puzzle, Journal of Finance,39(3), 575-592.

Myers, S. C., \& Majluf, N. S. (1984). Corporate financing and investment decisions when firms have information that investors do not have. Journal of Financial Economics, 13(2), 187-221

Pandey, I.M. (2001). Capital structure and firm characteristics: Evidence from emerging market, institute of management Ahmadabad, India.

Pandey, I.M. (2004). Capital structure, profitability and market structure: evidence from Malaysia, Asia Pacific Journal of Economics and Business,8(2), 78-91.

Titman S. and Wessels R. (1988). The determinants of capital structure, The Journal of Finance, 43(1), 1-19.

Yu-Shu, Y. and Chu-Yang, C. (2010).Capital structure and firm value in China: A panel threshold regression analysis, Africa Journal of Business Management. 4(12), 2500-2507. 